IRA-International Journal of Management \& Social Sciences

ISSN 2455-2267; Vol.03, Issue 03 (2016)

Institute of Research Advances

http://research-advances.org/index.php/RAJMSS

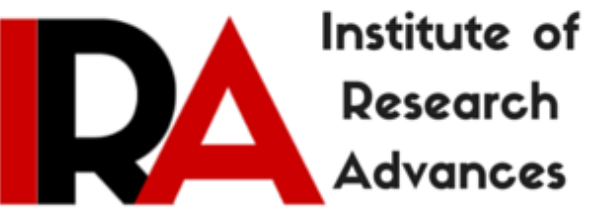

\title{
Semi-Month Effect in S\&P CNX NIFTY Turnover and Retail Participation in Indian Capital Market
}

\author{
S. Periyasamy, \\ Ph.D - Research Scholar, \\ Dept of Management Studies \& Research, \\ Karpagam Academy of Higher Education, \\ Coimbatore - 641021, India.
}

DOI: http://dx.doi.org/10.21013/jmss.v3.n3.p22

\section{How to cite this paper:}

Periyasamy, S. (2016). Semi-Month Effect in S\&P CNX NIFTY Turnover and Retail Participation in Indian Capital Market. IRA-International Journal of Management \& Social Sciences (ISSN 2455-2267), 3(3). doi:http://dx.doi.org/10.21013/jmss.v3.n3.p22

(C) Institute of Research Advances

\section{(c)) EY-NC}

This works is licensed under a Creative Commons Attribution-Non Commercial 4.0 International License subject to proper citation to the publication source of the work.

Disclaimer: The scholarly papers as reviewed and published by the Institute of Research Advances (IRA) are the views and opinions of their respective authors and are not the views or opinions of the IRA. The IRA disclaims of any harm or loss caused due to the published content to any party. 


\begin{abstract}
NIFTY is the bellwether index followed by most of the traders in Indian stock markets. The turnover in the S\&P CNX NIFTY constituent shows that the scripts are mostly traded on every session of trading. The study is carried out to check the semi moth effect in $S \& P$ CNX NIFTY which may helpful for retail investors to make investment decision. This study is carried out using the monthly movement of S\&P CNX NIFTY index of NSE India Ltd for the period April 01, 2004 to March 31, 2015. The statistical significance of semi month effect is tested using descriptive statistics and paired " $t$ " test. The outcome of the analysis shows that there is the presence of semi-month effect in index returns and suggestions to retail investors to time the investments based on the market movement.
\end{abstract}

Keywords: Capital Market, Seasonal effects / Calendar Anomalies, Monthly Effects, Semi-month Effect, S\&P CNX NIFTY - Market Index of National Stock Exchange India Ltd

\title{
Introduction
}

The movement of stock market indices denotes the movement of market which implies the economic well-being. The study on volatility in stock market prices and index have sailed through past century among academic disciplines and have a cumulative research evidence. Efficient Market Hypothesis (EMH) by Eugene Fama (1970) in simple terms, "Securities prices reflect information" is one of the highly researched areas of financial economics. EMH states arrival of new information in the market will immediately impact the prices of securities and thus the index also. The breakdown of EMH is evident when modern financial theory claimed highly controversial and often disputed the EMH in the modern financial world as the investors such as Rakesh Jhunjhunwala and Warren Buffett have consistently beaten the market over long periods of time, which by definition is impossible according to the EMH and when Indian stock markets crashed by 496.50 points which is $8.7 \%$ over previous trading session in S\&P CNX NIFTY in a single day (January 21, 2008) as evidence that stock market index can seriously deviate from their fair movement which is named as "Black Monday for Dalal Street". Adam (2004) states that security prices fully reflect all available information and will immediately adjust to the arrival of new information. The introduction of financial derivative contract happens at second half of the month and financial results of corporates and monetary policy announcement of RBI are announced on first half of the month. This paves way for investors to study the anomaly in market.

Semi-month effect in stock market Indices is that the market returns from the first half of the month are significantly higher than the second half of the month or vice versa. Arief (1887), who first provided evidence that the first half of the month had higher return than the rest of the days of the month by using The Center for Research in Security Prices (CRSP) data from 1963 to 1981 . He also found that the difference in returns was almost 1\% higher than first half of the month. Lakonishok and Smidt (1988) tried to examine the semi-month effect by using the Dow Jones Industrial Average (DJIA) data from 1897 to 1986 found that there no significant difference between the returns given by DJIA during the first and second half of the month. Arief (1887) suggested 3 major reasons for the existence of semi-month effect such as new information concerning corporate cash flow, changes in the risk free interest rate, changes in the preferences of market participants leading to variations in demand for securities, which cannot be offset 
by adjustment in supply need to be analysed before making investment decision in-order to make profits in the market.

\section{Review of Literature}

The review of research is to identify research gap and understand methodologies employed in the research area of Calendar Anomalies. Harvinder Kaur (2004) analyzed the nature and characteristics of stock market volatility in India and the US. The study found that the response to news arrival was asymmetrical, meaning that the impact of good and bad news was not the same. The return and volatility on various weekdays have somewhat changed after the introduction of Rolling Settlement. There was mixed evidence of return and volatility spillover between the US and Indian Markets. B. S Badla \& Kiran Jindal (2006) investigated one of the anomalies by segmenting pre and post rolling settlement. The result of this study found that the returns of the month effect and semi-monthly effect were prevalent in the Indian Stock Market. Guneratne B Wickremasinghe (2007) using the sample of 75 companies from Colombo Stock Exchange (CSE), found that there were no statistically significant differences among the returns for different days of the week. The analysis of this study indicates that the returns for the Month of January were not different from that of other months of the year. The study found that daily and monthly patterns of returns cannot be used to devise any method to profit from trading in shares in the Colombo Stock Exchange (CSE) Nageswari.P, Selvam.M and Karpagam.V (2011) examined the existence of Semi-Month Effect in Indian Stock Market. The study found that that the mean returns in the first half calendar month was lower than the mean returns in the second half calendar month during the study period. The paper reports an insignificant semi-monthly effect across all years except for 2005-06. Nikunj Patel and Martin Sewell (2015) from Nirma University and University of Cambridge respectively, in their review about Calendar Anomalies found that there are few research studies in the area of turn-of-the-month and semi-month effect in the market and the research can be focused in this area.

\section{Statement of the Problem}

The stock market index S\&P CNX NIFTY is widely accepted index by various stock market participants such as Foreign Institutional Investors, Domestic Institutions and Retail Investors to track the market movement. The significant difference between retail and institutions is that the institutions will follow markets across the countries and risk to get better returns for their investment by employing fund managers and financial market experts whereas the objectives of retail investors such as safety, liquidity and low risk appetite from their savings to meet their financial goals may not have adequate information's and time to watch their investments. Hence there is the need for retail investors to study the market anomaly to get the better opportunity to make profits out of their investment.

\section{Objectives of the Study}

The study intends to identify the Semi-Month Effect prevalent in S\&P CNX NIFTY index turnover based on the past performance between first half month and second half month for the period 2004-05 to 2014-2015.

\section{Research Methodology}

The study is analytical in nature. Secondary data was downloaded from historical data page of www.nseindia.com website for the Financial Year 2004-05 to 2014-2015. Descriptive statistics such as Mean, Median, Standard Deviation, Variance, Skewness, Kurtosis and paired " $t$ " test being used for analysis. 


\section{Analysis and Interpretation}

The analysis of semi-month effect in S\&P CNX NIFTY for the Financial Year 200405 to 2014-2015 is presented in Table-1.

\section{Table - I}

(Crores)

\begin{tabular}{|l|l|l|}
\hline Tools & First half of the month & Second half of the month \\
\hline Mean & 5676.5113 & 5855.5468 \\
\hline Median & 5590.2800 & 5706.5650 \\
\hline Std. Deviation & 2371.42520 & 2616.87441 \\
\hline Variance & 5623657.495 & 7027044.129 \\
\hline Skewness & 0.476 & 1.048 \\
\hline Kurtosis & 0.165 & 3.284 \\
\hline $\begin{array}{l}\text { Source: Database } \\
\text { Descriptive statistics) }\end{array}$ & collected from NSE website (S\&P CNX NIFTY turnover - \\
\hline
\end{tabular}

The analysis shows that there was highest (5855.5 crores) mean return recorded for the second half month than the first half (5676.5 crores) which is $3.1 \%$ higher. This indicates that the trading activity is higher during the second half of the month. The highest value (2616.8) and lowest value (2371.4) of standard deviation recorded for the second and first half month respectively. The highest value of standard deviation with higher mean return revealed there is linear relationship between the return and risk in S\&P CNX NIFTY returns during the study period. The peak of return distribution was platykurtic for the first half and leptokurtic for the second half month returns and highest (3.284) for the second half of the return series. The returns are skewed positive for both first and second half months during the study period.

\section{Determination of Semi-Month Effect - Paired ' $T$ ' Test}

To identify whether Mean return differs between First Half of the Month and Second Half of the Month using Paired ' $t$ ' test is employed and the outcome is given below using Table - II.

Table - II

\begin{tabular}{|c|c|c|c|c|c|}
\hline Semi Month & Mean & N & Std. Deviation & Paired t value & P value \\
\hline First half & 5676.5113 & 1337 & 2371.42520 & & \multirow{2}{*}{.009} \\
\hline Second half & 5855.5468 & 1337 & 2616.87441 & -2.624 & \\
\hline
\end{tabular}

Table-2 shows the results of paired ' $\mathrm{t}$ ' test analysis of semi-month effect in S\&P CNX NIFTY returns for the Financial Year 2004-05 to 2014-2015. The Mean return is found to be 5676.51 and 5855.58 during the first half and second half of the month respectively. As the calculated p-value is less than 0.01, there exists significant mean difference in returns between first and second half of the month. It is observed that the semi-month effect does exists in S\&P CNX NIFTY index returns during the study period.

\section{Findings and Suggestions}

The analysis of the turnover of S\&P CNX NIFTY showed that highest mean returns was recorded for the second half month than the rest of the days of the month. The one of 
the possible reason may be the salaried people may invest their portion of savings into at the beginning of the month. So it is suggested that the retail investors may invest during the first half of the month. It is also suggested to consider selling their holdings as there is greater volatility and highest turnover recorded during second half of the month. The Reserve Bank of India announces Monetary policy rates usually at the end of every quarter, Corporates announce their financial position at the beginning of the month and monthly return comparison by financial institutions come across the month shows that the retail investors may invest at the beginning of the month and advised to hold for long term which may help them in overcoming short term fluctuation.

\section{Conclusion}

The analysis on S\&P CNX NIFTY index shows that there is semi-month effect in returns generated has significant difference between first half and second half month for the study period. This paper confirms that the Indian stock market returns tested in the research are not efficient and there exists opportunities for superior returns. The earlier studies across boundaries also suggests that the anomalies are very strong and represent an opportunity to earn high returns by investing in the stock market for few trading sessions in a month. However, the study is based on the historical data, but the future market movement is affected by various factors such as Government decisions, transactions by institutions, income level of individuals, market irregularities etc., the retail investors may invest their portion of savings in diversified portfolio with the long term objective. The opportunity of making good returns by timing of investment and framing of investment strategies will help retail investors not only to safeguard their hard earned money but also to fulfill their financial goals.

\section{References}

[1] Ariel, R.A., (1987) "A Monthly Effect in Stock Returns", Journal of Financial Economic, Vol. 18, pp. 161-74.

[2] Ash Narayan Sah (2009) "Stock Market Seasonality: A Study of the Indian Stock market", Electronic copy available at: http://ssrn.com/abstract.

[3] Sanjay Sehgal and Srividya Subramaniam (2012) "A Search for Rational Sources of Stock Return Anomalies: Evidence from India", International Journal of Economics and Finance, Vol. 4, No. 4.

[4] Neeraj Amarnani and Parth Vaidya "Study of Calendar Anomalies in Indian Stock Markets", Electronic copy available at: http://ssrn.com/abstract.

[5] Dr. Pedapalli Neeraja and CMA. Potharla Srikanth "Anomalies in Indian Stock Market - An Empirical Evidence from Seasonality Effect on BSE IT Index", Journal of Arts, Science \& Commerce", Vol.-V, Issue - 3.

[6] Rohan Laxmichand Rambhia (2012) for NSE India Ltd "Exploring Risk Anomaly in Indian Equity Market"

[7] Vidisha Garg and Sahaj Wadhwa (2014) "Low Volatility Anomaly in India", International Journal of Commerce, Business and Management, Vol. 3, No. 1.

[8] Roopam Agrawal, "Seasonal Anomalies in National Stock Exchange", Altius Shodh Journal of Management \& Commerce", Volume: 01 Issue: 01.

[9] Natalia del Águila (2009) "Behavioral Finance: learning from market Anomalies and psychological factors", Revista de Instituciones, Ideas y Mercados, pp. 47-104 
[10] Michael C. Jensen (2002) "Some Anomalous Evidence Regarding Market Efficiency", Journal of Financial Economics, Vol. 6, Nos. 2/3, pp.no. 95-101

[11] Kadir Can Yalcin (2010) "Market Rationality: Efficient Market Hypothesis versus Market Anomalies", European Journal of Economic and Political Studies.

[12] Eugene F. Fama and kenneth R. French (2008) "Dissecting Anomalies", The Journal of Finance • vol. Lxiii, no. 4

[13] Miroslav Matteev (2004) "CAPM Anomalies and the Efficiency of Stock Markets in Transition: Evidence from Bulgaria", South Eastern Europe Journal of Economics, Vol. 1 , pp. 35-58

[14] S.K. Bundoo (2011) "An Analysis of Stock Market Anomalies and Momentum Strategies on the

Stock Exchange of Mauritius", African Economic Research Consortium, Nairobi.

[15] Melanie Cao and Jason Wei (2005) "An Expanded Study on the Stock Market Temperature Anomaly", Social Sciences and Humanities Research Council of Canada.

[16] Dr. A.L. Abdul Rauf "Seasonal Anomalies of Stocks in Emerging and Developed Equity Markets", Research Paper for College of Business Administration, The Kingdom University, Bahrain

[17] Donald B. Keim (1983) "Size-Related Anomalies and Stock Return Seasonality", Journal of Financial Economics Vol.12, pp.13-32.

[18] Bodla.BS and Kiran jindal (2006) "Monthly Effects in Stock Returns: New Evidence from the Indian Stock Market", The ICFAI Journal of Applied Finance, Vol. 12, No.7, pp.5-13.

[19] Guneratne B Wickremasinghe (2007) "Seasonality of Emerging Stock Markets: Evidence from the Colombo Stock Exchange", The ICFAI Journal of Applied Finance, Vol. 13, No.6, pp.43-65.

[20] Hareesh kumar V. and Malabica Deo (2007) "Efficiency of Indian Stock Market - A Case of Day of the Week Effect", SMART Journal of Business Management Studies, Vol.3, No.2, July - December2007, pp.28-35.

[21] Harvinder kaur (2004) "Time Varying Volatility in the Indian Stock Market", Vikalpa, Vol.29, No.4, October - December

[22] Jayan.B.Patel(2008), "Calendar Effects in the Indian Stock Market”, International Business \& Economics Research Journal, Vol.7, No.3, pp.61-69.

[23] Nageswari.P and Selvam.M (2010)", Day-of-the-Week Effect on the Indian Stock Market: An Empirical Analysis (Ed.) 2010”, 'Research Methods in Social Sciences' Ed. By Sundarapandiyan.P VHNSN College, pp.99-103.

[24] Nageswari.P and Selvam.M and Karpagam (2011), "An Empirical Analysis of SemiMonthly Effects: Evidence from the Indian Stock Market" Management in the Age of Innovation - NCM 2011, Ed. By Sheik Mohamed, Jamal Institute of Management, Arun Vasan Publishers, Trichy, pp.312-316. 
[25] Ravi Anshuman.V and Ranadev Goswami (2000), "Day of the Week Effects on the Bombay Stock Exchange", The ICFAI Journal of Applied Finance, Vol. 6, No. 4, pp. 3146.

[26] Selvarani.M and Leena Jenefa (2009) "Calendar Anomalies in the National Stock Exchange (NSE) indices", The ICFAI Journal of Applied Finance, Vol. 15, No.1, pp. 5667.

[27] Siqi Guo \& Zhiqiang Wang (2007) thesis "Market efficiency anomalies - A study of seasonality effect on the Chinese stock exchange" Umeå University, Umeå School of Business

[28] RN Bhaskar (August 2015) article - “\#BlackMonday: the bloodbath isn't over yet. Here's what's going on”, Catch News dated August 24, 2015

[29] Rajandran (2008) article - "Indian Stock Market Crashed on Jan 21, 2008", marketcalls.in dated January 22, 2008 